\title{
THE DEVELOPMENT OF TEACHER CHARACTERS BASIS OF TASAWUF
}

\author{
Afif Muhammad \\ State Islamic University (UIN) Sunan Gunung Djati Bandung \\ Jl. A. H. Nasution No. 105 Cibiru Bandung \\ Email:afifmuhammad.uin@gmail.com
}

\section{Dian}

State Islamic University (UIN) Sunan Gunung Djati Bandung Jl. A. H. Nasution No. 105 Cibiru Bandung

Email: diankutunggu@gmail.com

\begin{abstract}
This paper is based on the reality of education system in Indonesia which is still far from expectations, especially in shaping the character of teachers and students. In various cases, it is still found sexual abuse committed by teachers and students as well as the number of users and drug addicts among students. The purpose of this research is to find the root causes of problems and workable solutions to build the characters of teachers and students in the education system in Indonesia. The method used in this research is content analysis method. Data were analyzed using the approach of Sufism. This approach has three main methods which are, then, implemented in learning activities and interaction between teachers and students. The methods include takhally, tabally and tajally. Through takhally method, teachers and students are invited to have candor in doing to avoid the properties 'ujub, riya and disinterested. Moreover, tahally method becomes embedded properties of the pleasure meanwhil tawadhdhu' is act solely for Allah. Thus, these methods bear the loyalty of teachers, decrease negative rivalry and increase work productivity.
\end{abstract}

Keywords: Character, Teacher, Methods of Takhally, Tahally and Tajally

\section{ABSTRAK}

Tulisan ini bertolak dari realitas pendidikan di Indonesia yang masih jauh dari harapan terutama dalam pembentukan karakter guru dan siswa. Dalam berbagai survey masih ditemukan pelecehan seksual yang dilakukan oleh guru dan siswa serta banyaknya pengguna dan pecandu narkoba di kalangan siswa. Tujuan penelitian ini untuk mencari akar penyebab persoalan dan memcari solusi yang jitu untuk membangun karakter guru dan siswa dalam system pendidikan di Indonesia. Metode yang digunakan pada penelitian ini adalah metode analisi skonten. Data dianalisis dengan menggunakan pendekatan 
tasawuf. Pendekatan ini memiliki tiga metode utama yang kemudian dïmplementasikan dalam kegiatan pembelajaran dan interaksi antara guru dan siswa, yaitu metode takhally, metode tabally dan metode tajally. Melalui metode takhally, guru dan siswa diajak memiliki sifat ikhlas dalam berbuat hingga terbindar dari sifat-sifat 'ujub, riya dan pamrih. Melalui metode tahally, tertanam sifat-sifat ridha, tawadhdhu' dan berbuat semata hanya untuk Allah. Dengan demikian labirlah loyalitas guru, menurunnya rivalitas yang negative dan meningkatnya produktivitas kerja.

Keywords: Karakter, Guru, Metode Takhally, Metode Tahally, Metode Tajally

\section{INTRODUCTION}

According to the survey Political and Economic Risk Consultant (PERC), the quality of education in Indonesia was ranked $12^{\text {th }}$ of 12 countries in Asia. Indonesia's position is under Vietnam. According to the report of the National Commission for Child Protection from a survey done in 2007 in 12 major cities in Indonesia about adolescent sexual behavior, it shows really terrible facts that more than 4,500 teens surveyed, 97 percent of them admitted to watch porn. In addition, a total of 93.7 percent of junior high school teens and high school admitted to kissing, heavy petting and oral sex. Even more sinister again, 62.7 percent of teens admitted Junior High School was not a virgin anymore. In fact, 21.2 percent of high school teens claimed to have an abortion. These data for 2007, especially in 2008, would have increased even more.

In 2002 , about $70 \%$ of the 4 millions registered drug addicts as a child of school age, between 14-20 years old. Meanwhile, Director R.S. Marzuki Mahdi, Dr. Amir Hussein Anwar said that there were 500,000 injecting drug users in Indonesia who became HIV positive, in four to five years to come, which will draw them to be the new AIDS sufferers. The survey results Jogjakarta IPPA stated that there were 30 children boarding every month pregnant out of wedlock. PKBI Palembang stated that $20 \%$ of students having sex before marriage. And PKBI NTB had been doing the same survey and declared that any NTB teens have had sex before marriage. And Dr. Boyke Dian Nugraha, estimates that $20-25 \%$ of Indonesian teenagers have had sex before marriage, even based on BKKBN 1.6 million used abortions in Indonesia, $10-15 \%$ is done by teenagers. The rise of fighting among teens during the fasting month died many victims was the lack of great leader in cociety especially the younger generation in this country. In moral aspect, it was known as many as 6\% students of junior high school who were addicted to drug and almost $20 \%$ of students did free sex (SuaraMerdeka, September 18, 2008). 
Moral depravity of this nation seems to get more increasingly in the world. Some cases of violence and sexual abuse increasingly appear as the first violence. Worstly, there are done by the educator such as teachers on their students. In the end of 2008, the cases of violence and sexual abuse increasingly emerged. In questionable, will the cases of violence and sexual abuse flow naturaly or increasingly?

If we want to see the data of the treatment of sexual abuse in children, we will find the greatest percentage conducted by the teachers. The Commission of Indonesian Child Protection recorded that from 555 cases of violence on children $11,8 \%$ was done by teachers in 2007 . It is so worrying, isn't it? In fact, the salary of teachers will increase fantasticly. Why the teacher can do such criminal thing?

The fundamental question which distrub our conscience why a teacher who educated, voted moral values and deontology in all its behavior and deeds can act immorally, and degrade their moral selves? The answer is, of course, varied. There are some arguments that the profession of teacher did not correlate with moral matters. There are many cases such as in the prosecutors, the judiciary and other law enforcement agencies, absolutely, they understand the law matter but they made the legal problems of law for instance; corruption, bribery, and so on. It is also carried out in our representative court that should be as moral shield leaders of this country but they made the problem maker in corruption, and bribery matters.

On the other spectrum, the treatments of violence, immoral and amoral may not be triggered if there is no cause. There are various factors as the cause of those cases. For instance, briefly, a person conducts the corruption because of abundant wealth, wife, or his brother, fringe benefits, and others include the factor of human nature which is always dissatisfied. It is the appropriate reason as it is conveyed by the England Philosophy, Thomas Hobbes who stated that every man thinks of their selves and needs a good economy perfectly, however, human tends to try getting the advantage in each chance. According to Hobbes, the basic of human character itsef will trait humanity. Human identity contaminates bondage of world pleasures and the more people use wealth abuse, the more they make amoral on the weak people.

In other words, when the people satisfy themselves in the world, there were successful men but there were a few men who frustrated. According to Maurice Duverger, it is one of moral decreases which influences human conflict. In smaller aspect, the frustation can develop to be the deviant behavior, immoral, unlawful, arogant, unawareness on the others. Even in the network, there are the dominant people and weak people, it will be easy to cut the violence act, harassment, and threatment. (Mardiyanto, 
downloaded dated July 6, 2015 in http: //www.pelita.or Id / baca.php? id = 63 802).

On the other aspect, the development of character and nation identity of Indonesia is a manifestation of Pancasila and the basic Law Constitution mandate in 1945. Development of this character is based on the growing national problems today, such as disorientation and have not internalized the values of Pancasila; limitations of integrated policy tools in realizing the values of Pancasila; shifting the value of ethics in the life of the nation; waning awareness of the cultural values of the nation; the threat of national disintegration; and the weakening of national independence (Main Book Character Development National Policy 2010-2025).

Character education is not just to teach what is right and what is wrong, moreover, character education inculcate the habit (habituation) about where the good thing so that students become familiar (cognitive) about what is right and wrong, are able to feel (affective) value good and usually do it (psychomotor). In other words, a good character education should involve not only the aspect of "good knowledge (moral knowing), but also "feel good or loving good (moral feeling), and behavior (moral action). Character education emphasizes on habit or custom which constantly practiced and performed (Budi Handoyo downloaded on March 15, 2015). https://hangeo.Wordpress.com/2012/03/15/kendala-kendala implementasipendidikan-karakter-di-sekolah/.

Besides the character building, it needs to discuss in depth Sufism approach to develop the character of students and teachers. In Sufism terms, it is known into three purification types of human soul as follows: takhally, tahally and tajally. Thus, the method of takhally, tahally and tajally can be studied to develop students'character conceptually. The purpose of the study is to know how the development concept of teachers' character with the method of takhally, tahally and tajally, because the problem is not only the moral decadence lies in the students but also the teachers. The teacher who couldnot give a good behavior, it would impact on students' personality and attitude. Otherwise, habitual good action and the honorable attitude should be shown by teachers as an education firstly. The research of this study used content analysis method.

\section{DISCUSSION}

\section{The Essence of Human}

The human being is beter beings than all creatures that exist on earth. They have the advantages by which the other creatures don not have the strong stage in logical order. By their logical order, they are the only one who can develop culture continuously. In some people, the developement of 
culture gives the advantage thing on their life but the others are destructive. Both positive and negative effects influence each other, even blame each other, in their debatable ideas, they tried to develop who are the winner and the loser. It depends on the purpose of their life. The purpoe of their life will guide them to "paradise" or "hell".

There are many views on human identity, whether comes from human thinking or Scripture. For example Materialism believes that all creatures which exist in this universe are material and the human being is the part of those materials. Because humans are part of the material, materialism assumed that humans are not different from other creatures. This paradigm appeared in six previous centuries when the philosophers of Greec said that the nature of universe comes from the water, oil, air and fire. Those elements are material.

Islam says that human beings are created by Allah from two elements: earth and rub. Earth element is a symbol of the nature of matter, humility, humiliation, while the destructive element is a symbol of dignity spirit. Ruh is the substance, while the land is the bodies that embody the spirit.

\section{Character Building with Sufism Approach}

In doing something or not, there are three categories of human beings. First, the people who do something or or do not do something because of feared. For example, people who obey traffic rules because of fear of the police. Because the first attatntion is fear, when the dreaded doesn't exist he/she will carry out an offense. In accordance with the worship of Allah, in this people category, they carry out the command of Allah because they are fear on hell, if they do not carry out his command. Therefore, if the Hell does not exist, they will not obey to Allah's command. For example, in the social level, in a school regulation, teachers and students carry out the rule because of their fear to their headmaster. It is the opportunity to carry out the offense when the headmaster does not exist.

Second, people carry out something because they want to get praise from others. For example; some people do worship to get praise from others that can see their deeds as a good person. If there is no someone who sees them, they do not caryy out Allah duty (praying). In accordance with social life, they will carry out the duty if there is someone who sees and prises them. if there is no praise at all, they will not carry out their duty.

Third, the person teaches in earnest because of gratitude for all that he obtained. In the field of worship, he is grateful that Allah has made him a believer, gives enough rizki, and bestows good health to him in which he can live a good life. In the social level, such kind servant of Allah will strive in earnest to perform his duties, and complies with regulations set by the 
school; either when he supervised or not. Therefore, both in worship Allah and daily teaching, he has no other purposes, unless pleasure of Allah

The sincere people will not be affected by factors outside themselves, except Allah. The whole of their activities can be performed except of Allah. In addition, all activities are solely driven and intended to expect of pleasure, so thus there is no slightest space filled by something else. In other words, Allah became the center of the whole charity-actions, thoughts and his heart, as if it is completely filled by awareness of the pleasure of Allah, so that there is no gap left for that other than the pleasure of Allah. It is the message of holy Qur'an which describes that the sincere people can not be deceived by the devil.

Mysticism spirit (Tasawuf) is a conception of knowledge that emphasizes spiritual emotion as the method to achieve happiness and perfection of human life. The essence of Sufism actually has been around since the time of the Messenger of Allah.

Firstly, that Sufism is a further interpretation of the actions and words of the Messenger of Allah is loaded with dimensions spirituality and divinity. Sufism can not be known through the methods of logical or rational. In modern times, Sufism is getting interest of Muslims to practice the teachings of Sufism, especially, when the progress of the times has an impact on the human physical drought. (KokomKomariyah, downloaded on July 6, 2015 in http://komenkcb.blogspot.com/2012/03/konsep-takhali-tahali-dan-tajjali .html).

There are some ways to actualize the tasawuf aspect as follows: the stage of takhalli (emptying themselves against reprehensible nature), stage of tahally (adorn themselves with commendable traits) and stage of tajally (unraveling of the veil) (Mustafa Zahri, 1995, p. 65). More details refer to the discussion below.

\section{Takhally}

Takhally means if the servant who wants to close with his God, she/he must keep his or her spiritual emotion in negative atmosphere. In philosophical view, takhally is the hard level of spiritual approach because it is the rocess of purity of heart in negative thing except the good thing which is loved by God.

Takhalli means to clean or to keep our heart from any bad thing. It can be achieved by keeping our attitude from immorality which tighthens ourselves. According to the Sufis' group, immoral desire can be divided into two categories: physicaly and batin (spiritual). It is more dangerous than physical forms, because unawareness, it creates the people in doing someting worse. 
There are some negative characters that can damage a person's sincerity, whether in relationship with Allah, and human being in social life such as;

\section{Al-Riya}

One of the reasons in doing good thing is a will to be showed to others as if that they were good people who need a praised from others. However, it is the key of human's character. If there is none who knows their deed, they will not do it. Thus, the virtue of charity is not intended to get the pleasure of Allah, but human beings. This indicates an insincerity phenomenon. For example, when in the middle of the crowd, he showed himself as an expert worship, purely because they want to be regarded as a servant of Allah who are experts of worship, but when he was alone, he was lazy to do worship. Even so, it does not mean that charitable openly was prohibited. In fact, it is prohibited because someone wants to be seen and to get praised. The more they motivate others in good thing, the more they will get rewards from Gods.

Because riya' is the part of heart illness, the disturbances are very smooth. It moves from, namely, only the intention to shift the proper worship or charity aims to get the pleasure of Allah, be a charity devoted to praise his fellow human beings. Due to this concept, then, riy $a^{\prime}$ is so-called "small of syirik" (asy-Syirkul Ashghar), which according to the Prophet, it is such as "black ants, which runs on a black stone, which is concentrated in the night", is very faint and barely detected. However, the damage itself was incredible, "it decreases good deeds, like the fire that devoured the dry weeds". It destroys entirely.

Considering the dangers of riya' itself, there are several previous good people tried to hide their deeds well. Abu Bakar Shiddiq is the part of them. When the Messenger collected funds for the struggle, Abu Bakar intended to give his property in hiden condition. Waiting for quiet atmosphere beforehand, before he handed it to Rasullullah, he tried to give his money in hiden condition as if his left hand did not know what the right hand had given. Donations may be made openly, even according to a history, the reward is doubled, while those who do can avoid from riya'. But Umar ibn alKhattab actually did it in the crowded condition. He did it not for riya', but it is to stimulate and motivate on his followers.

In social interaction among human beings, the arrogant person (riya) will only teach seriously when he was in the social interaction and will show his obedience when someone was watching them out. But when he was in alone, he was lazy to teach, and he did the violation of rules because the aim 
of his deed is just for human attention. Such criteria will not be a productive employer.

\section{'Ujub}

Ujub is derived from 'Ajiba or 'Ajaba which means proude. In moral terminology, 'ujub is an attitude of self proude when doing something. Such a person considers himself very important, far above other people, who without him everyone else does nothing. When she managed to do something, he sees his success was because of the greatness of him instead of its cooperation with other people, especially Allah's help. When he and his friends managed to complete a good job, he considers that the success is due to him. The phrase "If there is no me, who knows what happened to this school," or "Because I was the only one he could as it is today", it is an appropriate determination of 'ujub which is in someone's heart.

The arrogant people in their teaching are those who want to be the important one. It shows pride and arrogance, which force them to be arrogant. In social interaction, this character will damage the cooperative tight. And further more will decrease social responsibility. Messenger put the terms of 'ujub with hunks indulge lust viewed as three destructive, "[There are] three things that ruin: miser who obeyed, lust-filled, and the pride of man against himself".

\section{Profit Oriented (Reward)}

The people who do thing with strings attached are people who need something in return. Typically, the rewards he hoped were material. However, there are also people who do things not because of the material, because they want to be praised. In fact, some are not for both, but simply because he wanted to satisfy his lust alone. People who engage in corruption, for example, are not the people who need the money, because they are rich who want to satisfy their desire.

Whatever the reason is, people who do things for reward are the ones who do not want to do anything without intention. Therefore, work is always conditional. That is, he will do anything, provided there is a will he get for himself. Without the benefits are, he does not want to do the whole hog. In conjunction with the worship of Allah, the human concern of this type is a reward from Allah in heaven. Even heaven and hell are the only thing which is the case of God's approvel and disapprovel.

Because the aim is reward, if the willingness is reached, he will stop there, and then enjoy success with it up. If it is not reached, he was disappointed and will not do it. In fact, it will probably hate it. In the social area, a teaching because it wants to occupy a certain position, will be determined to fight for his ideals, no matter how. If successful, he will get satisfaction and if it fails, he will do the destruction. 
It is better if we remember Ali bin Abi Thalib's message about some categories of people who worship to Allah. First, people who worship to Allah because of fearing to Allah decision. People who worship in this way is like a slave who does something because of fear of the whip lash of his master. Therefore, if ever adzab of Allah does not exist, surely he will not want to worship, even going to do a variety of violation and disobedience.

Second, people who worship to Allah are expecting rewards. These type of people make no difference to a poor employee, who did not want to do anything if there is no return. The reward for those who worship to Allah is heaven. So, people are disinterested would expect heaven in return for his worship. Though heaven or hell are the objects. Both are the result of the good pleasure of Allah or Allah's approval. Therefore, worship which expects a reply heaven, is a deviant worship, because someone was praying to Allah expecting to get the pleasure. That is why Rabi'ah al-'Adawiyah said, worship for fear of hell or hope of heaven is polytheists. Due to this thought, then once, in broad daylight, Rabi'ah out of his house with a staggering pace, while carrying a torch in her right hand, and a cup of water in his left hand. Seeing that, someone asked him, "Rabi'ah where are you going and what will you do?" Rabi'ah replied, "I'm going to burn heaven with this fire, and flush hell with this water, because both of them made many people become idolaters ".

Third, people who worship to Allah becausof his grateful to Allah. This is the worship of the wise, namely those who are familiar with the true Allah. They worship not because of fear of hell or hope of heaven, but because thank to Allah for abundance blessing and gifts. For them, the presence or absence of heaven and hell will not hinder their people worship to Allah.

\section{Tahally}

Tahally means ornate. It accustoms to act our selves by the character, attitude and deed well. It encouraged us try to act in line with the religious rules, whether the internal and external obligations or spiritual and physical forms. The physical obedience is an olication with formalistic form such as prayer, fasting, charity, pilgrimage, and so forth. Tabally is meditation or meditation are systematically and methodically, merging consciousness and the mind to be concentrated in the contemplation of Allah, the spiritual appoches which is done by a Sufi after having the process of purify of heart from the negative desires.

Tabally is a soul filling stage has been emptied on the level of takballi. In other words, after the self-cleaning phase of any nature and a good mental attitude can be passed, the effort must continue to the next level, namely tahally. In practice filling the soul with good properties after being emptied of bad qualities, it means that the soul must be emptied first and then filled. 
However, when eliminate of bad habits, along with that also filled with good habits.

Basically the human soul can be trained, controlled, changed, and formed by human will themselves. From the practice will become a habit and habits will result in personality. Mental attitude and actions are very important birth in the soul and familiarized loaded in the act in order to complete the formation of man, among others, repentance, patience, ascetic, trust, love, gnosis, the pleasure, and so on.

Tabally is biased with the characteristics of Allah. However, the most perfect jewelry and most pure for a slave is decorated with the properties of servitude. Servitude is full and perfect devotion and did not reveal signs of deity (Rabbaniyyah). Servant ornate (tahally) with servitude occupy eternity in itself and become nothing in the knowledge of Allah.

Tahally can also be interpreted as meditation or meditation systematically and methodically, merging consciousness and the mind to be concentrated in the contemplation of Allah, motivated by a very loud noise yearning to be the beauty of the face of Allah. Tahally is a fractional terms that do a Sufi after going through the process of cleansing the liver stained by worldly desires. Therefore there are several ways to adorn ourselves for them closer to Allah with sincere. To be human is sincere in worship to Allah, and teach with fellow human beings, positive values should possess the following:

\section{a. Lillah (Only for Allah)}

As noted previously, the duty of man as a servant of Allah is worship to Allah, which includes the relationship with Allah and his human being and Allah only accepts worship whichisperformed by sincerity.

Ikblas (sincerity) means pure. Water called pure, if it does not contain other elements except the water itself. Thus, worship sincerely to Allah, implies doing something that is commanded by Allah, solely to seek pleasure of his (Mardhatillab). Worship just like that alone is accepted by Allah, whereas worship is meant for something else [besides Allah] will not be accepted. Allah says, "And they were not commanded except to worship Allah with sincerity, solely because [execute commands] religion" (Qur'an, Al-Bayyinah, 98/5).

The sincere servant will not worship or charity to others than Allah, because that could be categorized as Syirk (associating partners with Allah), a sin that will not be forgiven by Allah. He tried hard to not give the slightest space in his worship, for other purposes, in addition to look for the pleasure of Allah. As the case of this person, he or she does something because of urging to get the material is nonsense. Therefore, human beings are the best creatures who have a mind and heart, so it is not appropriate for them to "be governed by the objects" dead and lacks like it. He also did not worship and 
teaching as fellow human beings. Because basically, man did not have anything can be expected for the safety of his life in this world and hereafter. As taught by the will and encouragement of self, is tantamount to deify her appetite. Therefore, for a Mukblishin like that, only Allah and his pleasure should be the goal. For him, pleasure of Allah is the best destination, which can not be exchanged for anything. Therefore, the material rewards, praise fellow human beings, and other purposes, never settled in his mind and heart. With all that, the work becomes a light weight. Any heavy work will he accept with joy, because it was he saw as increasing trust Allah to him. At the same time, he never questioned the so-called fail and succeeds in the job, regardless of the outcome because it is a definition of Allah's approval. Moreover, he never questioned whether he was taught as a boss or a subordinate. Therefore, the most essential thing for him is to teach and work, wherever and whenever he is.

Khalid Ibn al-Walid is classified as a servant of Allah who has such sincerity. In once time, when it has not been converted to Islam, Khalid Ibn al-Walid was a leaer of war of Quraish who highly haad been respected. Under his command the idolaters of Quraish managed to destroy the Islamic forces in the Battle of Uhud. When converted to Islam, he was also the Muslims who led troops in liberating various countries, and it continued until the reign of the uterus Umar Ibn al-Khaththab. The greatness of Khalid Ibnal-Walid who likes that, makes Umar Ibn al-Khattab, who was then serving as the Caliph, was worried that the men Khalid Ibn al-Walid would civilize him. Therefore, Umar then took off Khalid Ibn al-Walid from his post as commander and put him as a regular soldier. Responding to releas, Khalid said, "No problem. I did not strugglebecause of Umar, but because Allah", and Khalid keep fighting as a common soldier.

In his or her duty, a Mukblishin will devote attention and best effort, regardless of the material reward, praise peers, or expect promotion. He was convinced, along Allah's approval on worship and charity Allah will give him protection and help. Conversely, if he is not sincere, Allah will leave. If it happens he will lose strength. Thus his heart is completely filled with the hope of Allah's approval, so no matter how small the space is, it can be penetrated by a demon once. In the Qur'an told that when the devil does not want to obey Allah's command to prostrate to Adam, Allah gave the decision that in (the Devil) and all his descendants will be incorporated into hell. The devil accepted the decision, but he asks though on its implementation until doomsday. The devil, as manifested Quran says, "My Lord, [Because you bave misled me, and soon will be incorporated into Hell], then indeed I will definitely make the [crime] was wonderful for them, and I will mislead they all, except the servants are elected [as sincerity] "(Surah Al-Hijr, [15]: 39-40). 


\section{b. Tawadhdhu}

Allah confers advantages and disadvantages to each person in whic human complements each other. Any high knowledge and ability, he certainly has its drawbacks. Those who are experts in the field of economy, are less mastered the field of law. Those who are experts in the field of law, are lack of control in education. Those who are experts in the field of education, are not experts in the field of medicine. Through the principle of advantages and disadvantages, human life is driven, so there are mutualistic life movement and synergy between human beings and with reality as it is also in a school, requiring expertise in various fields in creating products. No one else field in this life can be undertaken without the involvement of many people with different kinds of expertise.

There are two ways done by people when they act the advantages and disadvantages among this people. The first one is haughty and arrogant attitude that highlight the advantages of self, and disregard the advantages of others, even merely saw from shortcomings. A character like this can be seen, for example, a boss yourself is against subordinate who considers his subordinate as lesser knowledge and expertise than him. Therefore, if he ordered his subordinate to do something then the command can not be denied or criticized. Contradicted or criticized him is an insult. "Did you understand?", That's the type of sentence that is often said.

It is also often happened to the relationship between parents and their children, teachers and students, husband and wife, the rich with the poor people, the strong and weak people. This way makes a person become difficult to accept the warning and advice and it will be a case which rirksthem selves.

The second way is the way a teacher who has a character of Tawadhdhu'. Tawadhu' is the humble attitude that emerges from a deep awareness of the lack of self and respect the existing advantages in others. With this view and attitude, the humble people (Mutawadhdhi) always see the positive values to others, and negative values to themselves. When they see the youngest people, they do not see them as "as the children" who do not understand anything, but on the other side the young people are not many sins yet when he has done a varieted sins and disobedience. When they are as boss, they do not see his subordinates as people who can not be commended but in the aspect of specific job the subordinates are much more understandable than himself. With the characters and the current perspective, a teacher who tawadhdhu' puts others as friends, colleagues, and friends from whom he can obtain a lot of valuable things. He or she believes that there are some weaknesses in themselves, therefore, they are always ready to accept a suggestion and advice from others. 
In accordance of this respect, Umar Bin Khattab, the famous Caliph with his brave and fairness was classified as the tawadhu'. Once upon a time, Umar Bin Khattab explained to many people, men and women about the dowry that a man must give to his future wife. According to Umar, dowry should not be high because such a thing would be difficult for people to do the wedding. Umar heard the explanation, an old lady standing said: "Amirul Mukminin, the Quran says that the dowry should be provided with a reasonable amount (according to the status of a person), doesn't it?" Then the grandmother recited verses relating to dowry problem.

In hearing the grandfa's critique, Umar Bin Khattab smiled and said, "Apparently, everyone is smarter than Umar now, she is right, and Umar is wrong" he said.

In a Mutawadhdhi, person likes Umar, there is no prestige or selfesteem issues that must be maintained with accepting the truth from anyone. That is in line with Rasullullah greeting, "find the knowledge, even to China". To study the knowledge even to China in Messenger era is the same as looking for knowledge to non muslim even Jews and the knowledge which will be learnt is not about Islamic religious

\section{c. Ridha}

"I'm willing to accept Allah as my lord. I'm willingly to accept that Islam as my religion, and I am willing to accept that Muhammad as my Prophet and messenger ", that is the promise of a believer who often taught to them since early childhood.

Willingness in the Arabic language is the pleasure. Ridha is deep awareness within a believer to accept something with sincerity without seeking other options afterwards. The pleasures all like it happened to him as he has done previously recognition, understanding and appreciation of something he has chosen. Therefore, he is fully convinced that the decision is something that is completely contained and therefore he does not need to look for other options. Ridha accepting Allah as Lord, means recognizing Allah as the Lord without looking for another option. Pleasure to accept Allah as the Lord is a choice that is most true, and so he felt that there is no need to look for the other options. It is similarly with pleasure of accepting Islam as a religion and Muhammad as a Prophet and Messenger.

The willingness to accept Allah as a God means the pleasure to accept his instruction rules and regulations without making other choices after that. Allah says, "And it is not fitting for men and women who are believers believers, when Allah and His Messenger have set a statute, there will be a choice of [others] to them about their affairs" (Surah, Al-Azhab, [33] : 36). 
A sincere teacher in teaching must accept with pleasure of all provisions has been decided by Allah, whether it is related with God (bablumminallab) and human beings and nature (bablumminannas). And would not choose another rule, because it is fully convinced that the rules of Allah will bring good for him, and the break will lead to disaster. With a sincerity that is based on the pleasure of such a character, he has a high loyalty to Allah, by practicing His commandments and avoids His prohibitions, regardless of reward or replies to be received. Whatever will she receive as a result of the attitude of His pleasure, will he accept it is with full sincerity. Extreme expression is, "Even if you put me to the hell, I will accept it with sincerity, My Allah, during the process of it will make you sincere to accept me"

If it has been done, Allah would be pleasure of him. Ridha Allah to His servant implies that Allah accepted His servants such as His chosen servant, who with it Allah will bestow goodness to him. Thus, Allah's approval came after a servant gives his total loyalty to him, then Allah's approval is met by the blessing of His servants. In the Qur'an says, "Verily, those who believe and do good, they are the best of creatures. Their reward with their Lord is Heaven 'And that flowed beneath rivers. They will abide therein forever. Allah pleasure to them, and they were good pleasure to bim. That is [reward] for those fearing Him (Q.S. Al-Bayyinah, [98]: 7-8)"

In accordance with his professional work, the teacher who has the pleasure of character will give loyalty to the school totally, as long as he found the advantage respects in the school where he teaches, that he has no attention to leave. In his opinion, how big or small income he receives, does not become a problem, because he has pleasure of fully to what will be given to her school. Thus, its purpose is not looking for material reward, but he gives the best for his school because he is fully convinced that the more he gives, the more he will receive.

One of the examples that we can take the lesson is the story has been experienced by Raeni ( 21 years old), the best graduate student of Economic Faculty of University of Semarang in 2014 who became public attention. Raeni was not from the rich family. His father, Mugiyono (55 years old) was only a rickshaw puller, and his mother was a housewife. Student who graduated with a grade point average (GPA) of 3.96 is known to have personally learned. She often went to mosque early when she heared the adzan called every time, the own dorm, Qoyimah (42 years old) said. Raeni's dormitory in Jl. Kalimasada No. 24, Semarang was the firts wittness of Raeni's struggle in her successful education at the State University of Semarang. "She often worshiped in each time. In each adzan call, she must go to pray at the mosque and she often recite the Quran, when she came to 
Qoyimah's dorm, she also has the high understandable of religious background," said Qoyimah.

In her religious characteristic background, Raini is the enteracted girl with others around him. Her friends recognized her as good girl whether in her dorm mate and her friends. Although she came from the poor family, Raini tried to show her excellence and achievement.

In the story above, it explains that Raeni is a success girl. In the behind her success, she is a religious girl in worshiping on God (Allah Al mighty) and sincerity recieved all the circumstances that existed him without whining and grumbling.

To create a sincere personal character is not an easy matter. The education orientation on character building often tries to improve in other that teachers and students have qualited character but But in fact, to create the good teachers and students character is not an easy task. It needs the process and associate from other society wehter in family, school, or environment.

\section{Tajally}

After passing two stages,someone will pass the third stage of the tajally, someone's heart liberated from the bad matters (hijab) it is a human characters or gainedspiritual improvement of "nur" that has been losed or mortal everything other than Allah when it appears (tajally) His face.

Tajally means enlightenment or disclosure. A term that developed among Sufism as an incarnation, embodiment of a singular, an inner light emission, revelation of God, and enlightened heart of good servants.

Tajally is unfolding curtain cage of the supernatural, or the enlightened of nursupernatural, as a result of a meditation. In Sufism, the process of unraveling of the curtain and acceptance nur unseen in the heart of a mediator is called $\mathrm{Al}-\mathrm{Hal}$, namely the appreciation of the unseen which is a gift of God and beyond human will.

Tajally means Allah reveals Allah himself to His creatures. Allah's disclosure never repeats the same and it never ends well. Allah's selfdisclosure form batiniyah light that enters the liver. If a person can go through two stages tajally, takballi and then he will reach the third stage, namely tajally, which means disappeared or loss of humanity or numijab explained that as long as it is hidden or fana ' everything except Allah, when it seemed the face of Allah. Tajally is a sign that Allah instilled in people so that he can be watched. Each light-by-light tajally bestows so that a person who received it will sink in goodness. In case of differences that were found in a variety of disclosure, it does not indicate a dispute between Sufi teachers. Each human being is unique, therefore each tajally is also unique. Thus, there is no two 
peoples feel the same tajally. Tajally is over the words. Tajally is spiritual power. Al-jilli divides tajally into four levels.

1) The deed of Tajally (Tajally Afal) is Allah's tajally to someone's deed, it means that all these activities are accompanied by his destiny, and when He saw him.

2) The names of Tajally (Tajally asma) is the disappearance of a person from himself and free from the grip nature novelty and the loss of body bonding ballpark. In this stage nothing is visible except the One Ash Shirfah (the essence of the movement), not seeing asma :

3) The character of Tajally (Tajally Sifat) is to accept a slave on nature divinity, meaning that Allah took the place without His hullulessence.

4) The Subtance of Tajally (Tajally Zat) is Allah allows the tajally to His servants who deprive him then took him to be a divine bless and can also be the nature of the substance is, there occurs a perfect singularity. Only a temporary servant then baqa` is only for Allah.

Sufism said that Sufism otherwise carries out takhalli, tahally, and tajally. The way taken by the Sufis are takhalli, tahally, and tajally. Emptying the soul of vices, adorns the soul with good properties for the purpose of witnessing the breathtaking sight that the real Allah does not exist, only Allah is there, "There is no Allah (lailâha) apart (illâ) Allah and Muhammad bin Abdullah is a servant, messenger, and his love "

Ibn Arabi stated that there are two forms tajally of Allah, as follows: supranatural tajally or substance tajally and absolute tajally (tajally sbubudi). AlKalabadzi divided tajally into three categories, as follows:

1) Substantial Tajjaly (Tajally Zat) is mukhasyafah (the enlightment of spiritual dimension with God).

2) The Az-zat characteristic Tajally (Tajally sifat Adz-Dzat), seems that the the characteristic of Allah is as the sources or the poace oflight.

3) The Az-dzat Law Tajally (Tajally Hukma Adz-Dzat), seems that his substatioal of law is matters relates with the here after and the determination of human relationship with God called as "Makrifat".

It is the key of spiritual comprehend. If the someone can reach it he or she will feel the tajally itself. If he or she feel the tajally or takhalli and the other respect relate with the improvement of spiritual dimention (makrifat). Tajally means to achieve a good servant in the sight of Allah, or the subliming person. When she or he reaches that level, the heart will feel safety. In java wise word is "sepiingpamribrameinggawe". But the fact that the meaning of tajally has very broad meaning. It is the terms of taswuf in Tarekat dimension. If the liver can lay deserted apart from Allah it means it will find one takhalli, as 
the pleasures, delights, the sweetness because it can release everything other than Allah and His Messenger.

In terms of teaching, it seems some of the indicators that are attached to a teacher, among others:

1) The loyalty of teachers on students is getting improvement.

2) The more decreasing of signed rivality, the more decreasing of gosib and issue of slender.

3) The request which has been not included in productivity has decreased more.

\section{Educational Implications Sufism in Building Teacher Characters}

Moral education and Sufism is needed by every individual and society, because of its good positive influence will be felt by individuals and society in equal portions, as well as the negative impact, when it is be littled, it will spread to individuals and society and educational Sufistic vertically can be able to good improve morals and worship to the Allah Almighty and horizontally, it will create a good moral each society. In educational respect, moral education and Sufism is needed by the teachers, especially in their function as educators to be able to transmit a positive personality and knowledge to the students and have a great attitude both to the creator of universe and its creatures.

Moral decadence and abuse attitude that occurred in most of the teachers and students are caused by the atmosphere of tarbiyah or poor education. Thus, we need an education which is able to bring us and our children to have a good moral which creates us happiness and safety.

The need for educational sufistic or moral requires an educator in order to keep their students from evil and ugliness, like a spreading hostility, discos, and the place filled with anger, because in Islamic education, the real appreciation on morality, (morality) becomes the standard of success. Understanding morality, indeed, can not be able to comprehend it automatically. The understanding of morality of course is going to be a good and improtan on each student. But the understanding of morality is only in their ideas, it surely does not be received in their heart and feeling yet. Obviously with education Sufi, teachers and students probably will not do the bad things like crime, cruelty and arbitrariness, because if it came and attached into their hearing, it will be difficult to far away in the mature growht and the parent or guardian will find the difficulty in keeping them from themon the bad matters. Ibn Qoyyim says on this matter, "which is needed by the child is his attention to morality (Al-Hizajy, 2001: 107)." [5]

This description is an explanation of the importance of Sufisticeducation, whose realization in addition to get closer to Allah, it can 
also keep children and protect them from falling and being human is low and despicable, and not drowned in word and indecency. Custody and debriefing as this would be the child clean and ready to receive goodness in the form of words and deeds.

To reach this stage, there are some stages must be thought over and actualized by teachers:

1) Accustome to keep teaching well, even there is no one who sees or supervises.

2) Start to have an attention in every work by paying, minimally by reading bismillah, thus that all activities undertaken relate with Allah Almighty.

3) Accustome to receive with pleasure hearth when receiving an advice, rebuke and critique, because all of them for are for our elves.

4) Dzikir in every opportunity, especially after the obligatory prayers.

5) Modeling of leadership in providing guidance, assistance, and a sincere attention on employers.

6) Gathering, whether in experience sharing or activities in both in the form of shared experience, as well as joint activities in society service activities.

According to Muhammad Nasih Ulwan (1981: 163-173) the process to create religious values-based awareness of divinity (education sufistic) can be reached in three ways:

1) Improving values gradually, from the physic to the rational form, from the partial to the universal, and so on.

2) The Application of soul khusyu', taqwa, and worship, absolutely, it is difficult to be actualized butif the children were given a warning, he will change his character.

3) Awareness of Allah control in every behavior and situationcan be applied by practices and belief.

According to Munir Mulkhan (2003, p. 25) stated that the method of sufistik education is as following:

1) Learning activities began with the effort in other that students define who they are, what will be chosen, and aware of the risks that would be faced with the choice. Next, students draw up their own concepts of truth and goodness in their view that could be their own. It is expected to be growing social sensitivity in the willingness to share the taste with others. Next, they will grow with intact and round as a basis for them to train their divine intuition and imagination, as well as train the ability of rational intelligence. 
2) Learning methods oriented divinity learning situation. It can be expected that students can do their creative process themselves in devineprocessand Islamic belie. It showed that students can find themselves and realize the presence of Allah in the classroom or everyday life. Personal awareness as it is the primary key for the learning process of growing the creative power that is free and independent of each learner. Hopefully, students continue to enhance the knowledge of the teachings of Allah and its fulfillment so that a good kaffah during the learning process in the classroom or outside the school environment and in social life after their school later (Abdul Minir Mulkhan, 2007, p. 79).

3) Envolving students in every knowledge process of the study of nature and humanity. The main purpose is to find and know God by themselves (Abdul Minir Mulkhan, 2007, p. 79).

4) Ritual practice and moral practice are arangement. Based on religious teachings include faith, morals, and worhip, more strategic if religious education is focused on enriching experience of Allah (faith), ritual (worship), and character, not just science. Enrichment can be reached through the ritual experience. Enrichment experience of Allah is through the study of history of success stories and failure of everyday life or the history of the nations of the world. It is also through the study of physics, biology, chemistry focused on the greatness of Allah created the universe and all living things from the lowest to the energy levels and the man (Abdul Minir Mulkhan, 2007, p. 79).

\section{CONCLUSION}

The educational system has been built in Indonesia integrated the relationship capability among affective, cognitive and psychomotor aspects. The most striking issue is precisely the affective aspect. Morality, in this aspect, social response and strong behavior become the main character. In fact, scorn and ridicule respect on the education system in Indonesia became hot debatable everywhere. The existence of sufistic approach in educational management became a real answer to overcome the problems above. The method of Takbally, tahally, and tajally has been built in Sufistic approach is able to convince positive characters and good personality for teachers. Through takhally method, teachers are invited to have sincere characters in their deed in such far away from arrogan and profit oriented characters. Through tabally method, it is created the sincere characters, humble, and doing just or Allah. Otherwise, it improves the loyality of teachers, negative revality decrease to bear the loyalty of teachers, decreasing the negative 
characters and increasing the work productivity. Thus, the building of teacher characters is better to be applied in broader scope especially in educational system of Indonesia in each educational level.

\section{BIBLIOGRAPHY}

Ulwan, Abdullah Nasih., (1981). Tarbijah al-Aulad fi al-Islam, Cetakan kedua. Beirut: daar al-Salam.

Mukhan, Abdul Munir., (2003). Cerdas di Kelas Sekolah Kepribadian: Rangkuman Model Pengembangan Kepribadian dalam Pendidikan Berbasis Kelas, Yogyakarta: Kreasi Wacna.

Al-Hijazi, Hasan Bin Ali., (2001). Manbaj Tarbiyah Ibnu Qoyyim, Jakarta: Pustaka Al-Kausar.

Zahri, Mustafa., (1995). Kunci Memahami Ilmu Tasawuf, Surabaya: PT. Bina Ilmu.

Kokom Komariyah., (2012). Konsep Takhally, Tahally danTajally, dalamhttp://komenkcb.blogspot.com/2012/03/konsep-takhali-tahalidan-tajjali.html downloaded on 6 July 2015.

Mardiyanto, downloaded on 6 July 2015 in http://www.pelita.or.id/baca. php?id=63802).

Budi Handoyo., (2012). Kendala-Kendala Implementasi Pendidikan Karakter di Sekolah dalam https://hangeo.wordpress.com/2012/03/15/kendalakendala-implementasi-pendidikan-karakter-di-sekolah/. Downloaded on 15 March 2015. 